\title{
Class Formation and Workers' Attitudes toward Education: La Pensée Ouvrière (1948) by Georges Duveau
}

\author{
Michael Hanagan
}

Vassar College

\begin{abstract}
La pensée ouvrièrere pendant la second république et le second empire, Georges Duveau's classic but largely-forgotten study of French artisanal workers, focuses on changing attitudes toward work and education between 1848 and 1870, years which Duveau himself lauded as exceptionally fertile and creative in French social thought. How to explain such extraordinary fecundity? Partly, it can be explained by intensified police repression after Napoleon III's coup, when the educational institutions of workers were repressed and they had to design new ones under the eyes of a suspicious state. Perhaps a more important factor, one suggested by the recent work of Thomas Piketty, is the ever-growing need to produce workers capable catering to the ever more sophisticated needs of the fabulously wealthy. The highly skilled artisanal production in Paris combined with the growth of factories created the distinctive conditions of French economic growth.
\end{abstract}

Almost every historian has a short list of books he or she considers unjustly neglected. On my list is La pensée ouvrière pendant la second république et le second empire by French historian Georges Duveau (1903-1958). ${ }^{1}$ Here Duveau, looks at debates over educational policy within a labor movement dominated by skilled workers during the years of the French Second Republic and the Second Empire (1848-1870). The seamless merger of social, economic, and political forces, a sophisticated view of the role of educational policy in popular consciousness and a skillful manipulation of the unusually valuable popular sources on the period give this book a coherent perspective on class formation at a key moment of French labor history.

Duveau saw education - at home, in the workshop, and in the school-as a key element in class formation. His sense of the relationship was doubtless strengthened because at the same time that he was writing his book on education and class formation, Duveau was working on a larger, more comprehensive study of working-class life. In 1931 he entered the National Center for Scientific Research (CNRS) and began work on a thesis, La pensée ouvrière pendant la second république et le second empire, which he completed in 1944, submitting simultaneously a second supporting thesis. ${ }^{2}$ This second thesis, La Vie ouvrière, was a sweeping study of working-class social life in France between 1851 and 1870 with particular emphasis on the ways in which occupational characteristics of the labor force and urban form shaped worker militancy. Duveau's study of workers' attitudes toward education was intended to be inscribed 
within the larger study. Over this same period Duveau published many books, including an edited collection of the works of the social thinker Pierre-Joseph Proudhon (1809-1865), an important influence on Duveau's thinking. ${ }^{3}$

Using reports of workers' delegations to international conferences, public speeches, and parliamentary committees established during the revolutionary years, Duveau pays attention to ideas about educational policy circulating among skilled workers, then practically the only section of the working class that left written records. Debates among skilled workers over educational policy give a perspective on class formation unavailable elsewhere because they reveal workers' own ideas about how skills should be transmitted, the ways in which work was actually experienced, and workers' future expectations for themselves and for their children. The debates of the 1850s and 1860s were exceptionally interesting because they were also related to larger debates going on within society among politicians and scholars. An emerging workers' press, the loosening of censorship laws, and the publication and circulation of politicized almanacs and pamphlets familiarized some French skilled workers with radical ideas, such as the educational theories of Charles Fourier (1772-1837) and Etienne Cabet (1788-1856), decried by Marx and Engels as "utopian socialists." Both Fourier and Cabet imagined ideal communities designed to attract imitators but also as models to criticize existing institutions. According to Fourier and Cabet, using rather formidable classification systems, the new model societies they championed would assign work according to individual capacities and predilections. Basically, however, such classifications came down to simple criteria - for example, children who liked to play in the mud might be farmers while those who loved noise might be destined for factory work. Work would be a pleasure. ${ }^{4}$

What did workers with decades of experience in workshops think of utopian socialists' criticisms of the education available in contemporary workshops and the educational methods found in Fourier's phalanstères and Cabet's Icarian communities? They were not unanimous. Many highly-skilled workers were sympathetic to the utopian socialists, but many others disagreed. Some dissidents adopted the ideas of Pierre-Joseph Proudhon. ${ }^{5}$ Destined for a university career, Proudhon became a worker after his family's firm collapsed. His knowledge of Latin, Greek, and Hebrew enabled him to find work as a typographer for academic books. Proudhon spoke with both the authority of someone with experience in the workshop and with the credentials of what we might now call a "public intellectual." He denounced schemes like those of Fourier or Cabet that destined workers to repetitious practices that must inevitably stifle human creative powers: better for workers' education to familiarize themselves with several different forms of work even if they mastered none, than to build a world of narrow-minded specialists unable to discuss large issues.

Proudhon's view of this matter was embraced by Marx and Engels and became a well-known tenet of Marxist thought. Famously, Marx and Engels maintained that “... in communist society, where nobody has one exclusive sphere of activity, society makes it possible for me to do one thing today and 
another tomorrow, to hunt in the morning, fish in the afternoon, rear cattle in the evening, criticize after dinner, without ever becoming a hunter, fisherman, shepherd or critic." ${ }^{6}$ Marx and Engels derived these ideas from followers of Proudhon. $^{7}$

Debates among utopian socialists and Proudhonians and, later, Marxists about the organization of work and the organization of education captured one dimension of the education controversy, but the debate was more comprehensive and inclusive. Proudhon's ultimate educational curriculum was something resembling a liberal humanistic education imparting a broad training, enabling all to participate in social and political discussions. ${ }^{8}$ He was an advocate of local control of education and believed that schools should be transparent institutions, oriented toward local society. Teachers colleges would be established in every county seat and so open to immediate inspection by everyone. ${ }^{9}$ Parents (but mainly fathers) would have the ultimate say on teachers. Proudhon had a highly gendered view of society, and women were banished to the household by this highly erratic thinker.

As Duveau shows, the diversity of educational ideas available to workers in this period was breathtaking. "Education for citizenship" was one slogan that reemerged from the debate; it harkened back to the radical phase of the French Revolution drawing on Louis Antoine Léon de Saint-Just, the young friend of Robespierre, who believed that the republican state should "educate, lodge, nourish and dress young citizens." 10 A less radical and more popular and enduring slogan, "Free, compulsory and secular" education was espoused by Jean Macé who in 1866 founded the Ligue de l'Enseignement, the bearer of republican orthodoxy on educational policy during the Third Republic (1870-1940).

Among the ideas sketched out in this era, but little known until later (1918), was a design for secondary education known as the "école unique." In the école unique, as in many American high schools, students advanced from grade to grade, following a similar curriculum. ${ }^{11}$ The idea of the école unique would increasingly dominate educational reform in France into the modern era. A few workers even argued for education to combat chauvinism, racism, and male chauvinism, but these remained far on the fringes of the educational world. ${ }^{12}$

All evidence suggests that the years 1848-1914 were years of remarkable popular interest in education. Who were the workers of this period so obsessed with education, and why were they so deeply involved in thinking about educational problems? Duveau does not really address these issues, but recent scholarship provides some suggestions. To understand this obsession, it is necessary to understand the identity of these workers and their context in the larger society. In the late eighteenth century, London, which had long competed and even bested Paris in luxury goods production, began to lose out to its Parisian rival. As Sargentson notes, "Paris became the international market for luxury goods."13

Nineteenth-century Britain is well known for its industrial revolution, but France had two economic revolutions, although the second is often ignored. France's first economic revolution was similar to Britain's. In the French coalmines of the Nord and the steel works of Saint-Etienne, there was a supply- 
based revolution like the British industrial revolution including mass production, the growth of a less skilled, industrial proletariat, and a huge wave of cheap commodities for a national market that the new workforce could afford. This new labor force required literacy and a few months of on-the-job training but little else. But in France, especially in Paris, but also in cities like Lyons, there was a second revolution, a demand-based revolution based on quality-good production, by highly skilled workers producing very expensive products for a worldwide elite.

Long ago, Kederer and O'Brien noted that, over the course of the nineteenth century, while the British economy was concentrating on mass production, the French economy was diversifying, a significant portion producing high-quality goods. ${ }^{14}$ In her study of France in the second half of the nineteenth century, Walton notes that "though large-scale, mechanized industry did develop during the second half of the nineteenth century, small-scale, handicraft manufacturing remained substantial and declined only slowly in this period." 15

There was nothing traditional or backward-looking in the evolution of French industry in the second half of the nineteenth century. In 1852 Parisian luxury goods makers were startled to hear of the opening of the "House of Manufacturers" (later known as the Victorian and Albert Museum). It could act as an education resource to help boost productive industry. London luxury goods producers would have all the art of the past available to them for imitation. Faced with competition from British industry, French skilled workers needed systematic training. As Paris rose to preeminence in luxury goods production, it needed effective educational institutions.

According to Georges Duveau, between 1851 and 1870, white, male skilled workers in France, supported by workmates, neighbors, and family members, tried to construct institutions for training highly skilled workers. In most of Europe and the United States such institutions had long been in place. Guilds, compagnonnage, employer-controlled apprenticeship programs, and craft unions and all manner of customary institutions had all served these functions under the ancien régime. ${ }^{16}$ But the dissolution of the guilds by the French Revolution and the prohibitions against worker organizations in the aftermath of the failed French revolutions in 1830 and 1848-1851 deprived French workers of many such institutions. Many French workers therefore called on the government to aid the luxury trades and to support an expanded system of artisanal education.

Perhaps the greatest pressure for expanding education in the world of Parisian luxury goods production was the increasing proportion of the very wealthy, of whom were the principal consumers of Parisian decorative arts. Here Thomas Piketty's remarkable book on long-term changes in the distribution of wealth in the twentieth century is helpful. ${ }^{17}$ If Piketty is right, the growing social inequality of the second half of the nineteenth century up to 1914 further favored luxury consumption, with a declining proportion of the population receiving a disproportionately large share of the money. At the top of the social hierarchy was a growing class of ultrawealthy men and women for whom the consumption of high-quality goods meant no sacrifice in their living standards. 
In this way, the interests of the very wealthy and the very skilled coincided. Thanks to Georges Duveau, we have a much better understanding of the educational dynamics of the luxury demand economy of nineteenth and early twentieth-century France.

\section{NOTES}

1. Paris, 1948.

2. La vie ouvrière en France sous le second empire (Paris, 1947).

3. J.P. Proudhon, La révolution sociale démontrée par le coup d'état du Deux-Décembre (Paris, 1937).

4. La pensée, $150-51$

5. On Proudhon, see Robert L. Hoffman, Revolutionary Justice: The Social and Political Theory of P.-J. Proudhon (Champaign, 1972).

6. Karl Marx and Friedrich Engels, The German Ideology (Eastford, CT, 1932).

7. Armand Audiganne, Les Populations ouvrieres et les industries de la France (Paris, 1854).

8. La pensée, 205.

9. Ibid., 156.

10. Ibid., $157-58$.

11. Ibid., 191.

12. Ibid., 208.

13. Francois Crouzet, French Economic Growth (Stanford, 1975).

14. Patrick O'Brien and Caglar Keyder, Economic Growth in Britain and France, 1780-1919: Two Paths to the Industrial Revolution (London, 1978).

15. Whitney Walton, France at the Crystal Palace: Bourgeois Taste and Artisan Manufacture in the Nineteenth Century (Berkeley, CA., 1992).

16. Compagnonnages were working-class institutions originally run by the French.

17. Thomas Piketty, Capital in the Twenty-first Century (Cambridge, 2014). 